\title{
E-GLOSSARY AS A LEARNING RESOURCE
}

\author{
Katarina Milosavljević, \\ Dalibor Marijančević, \\ Tijana Gajić
}

\author{
Singidunum University, \\ 32 Danijelova Street, Belgrade, Serbia
}

\section{Correspondence:}

Katarina Milosavljević

e-mail:

kmilosavljevic@singidunum.ac.rs

\begin{abstract}
:
In the present information era, it is almost unthinkable not to use the Internet in business, teaching and everyday life. In this paper, the use of the Internet in foreign language teaching and learning is being discussed. As an example, e-glossary is used. E-glossary is developed through students' own effort. The students learn English as L2 and German as L3 at Singidunum University in Belgrade. The glossary is compatible with curriculum and with the vocabulary level taught during the three years of study. This glossary is a bilingual one used to translate words and phrases from German to Serbian and vice versa. It consists of the vocabulary needed for A2 level of competence according to the European Framework of Reference for Languages https://www.coe.int/t/ dg4/linguistic/Source/Framework_EN.pdf. The fact that this glossary has been fully developed by students should be particularly emphasized.

The first part of this paper is dedicated to the development and programming of the glossary itself using JAVA programme. E-glossary of this kind is a synthesis of philological and IT skills. A few generations of students have been using it mainly because it is practical and can be easily installed.
\end{abstract}

Key words:

e-glossary, foreign language teaching, foreign language learning, the German language.

\section{INTRODUCTION}

It is impossible to programme e-glossary without a programming language knowledge. E-glossary usage and new words addition are both impossible without the German language and grammar knowledge. This paper is intended to be a unique combination of informatics and philology. Advantages and disadvantages of the e-glossary will be described, as well as the reasons for its development. Furthermore, we will offer some useful examples, taken from the German course, held at Singidunum University, as well as a detailed explaination for using this kind of eglossary, followed by pictures. The second part of this paper is dedicated to JAVA programming language and reasons for the choice.

E-glossary is only one example of using the Internet in foreign language teaching. Additionally, Moodle platform, specialized websites and youtube channels especially created for foreign language learning are being used. According to the questionarre results Ferčez got, students of technical faculties recognize the importance of learning English and they realise how helpful it is in using the Internet. Almost all manuals and warnings are in English (Ferčez, 2006:118) English is very important 
not only in everyday communication but also in IT field. Computer programmes are being changing so fast that literature and manuals which are originally in English cannot be translated at that speed. Some of the words or phrases within IT field are often untranslatable, so they remained the same. At Singidunum University, Faculty of Informatics and Computing, students, except for English, learn second foreign language. The results of a survey conducted by Šimunović show that approximately $60 \%$ of students recognize the importance of learning two foreign languages and $40 \%$ of them are either reticent or they think that learning two foreign languages is of minor importance to them (Šimunović, 2013:221). They learn language traditionally, at school or faculty, but also at home, using the Internet. The research done by Gabrilo and Rodeka shows that majority of students consider traditional lecture learning more efficient than the so-called Internet learning (Gabrilo and Rodeka, 2009:297). The combination of various learning techniques is considered to be the best. The Internet usage in language teaching should primarily depend on the group itself and students' learning styles.

\section{ELECTRONIC AND TRADITIONAL GLOSSARIES}

At the very beginning, the difference between the concepts of glossary and dictionary will be explained. The glossary is a small dictionary which offers explaination/translation of the word or phrase, but it does not offer grammatical, phonetic and phraseological explainations. The comparison between traditional end electronic dictionary is emphasised here. The aims are the same but the usage is quite different. This comparison is similar to the comparison between traditional and e-book. E-book has lots of advantages: it saves our time and space, it is easily portable, it cannot be easily damaged, it is easily searchable by keyword etc. Jeremić V. stresses the fact that e-book also means equality because of knowledge availability via the Internet (Jeremić, 2010: 68). On the other hand, e-book has also its disadvantages, such as sight damage, there is no possibility of a dedication of a book, there is no spiritual value as in the case of traditional or paper book. It is the same with dictionaries. E-dictionary is easily portable and searchable, mostly free of charge and exremely systematic. Traditional dictionary can be heavy, word search takes more time, it is usually expensive and unavailable. If we conducted a survey about the students' usage of dictionaries, we would reach to the conclusion that e- dictionary is a lot more used. There are bilingual and monolingual dictionaries. Google translate is probably the world-renowned bilingual dictionary. This dictionary is very useful but we should also bear in mind that it often ignores the context, grammmatical and other characteristics of the words. As an example of a monolingual dictionary, we offer the most famous online German dictionary DUDEN http://www.duden.de/. As a result of a word search in DUDEN dictionary, we have not only translation (descriptive explaination in German), but also word's grammatical characteristics, synonyms, the main collocations and the frequency of its usage. In addition to DUDEN, DWDS- Das Digitale Wörterbuch der deutschen Sprache http://www.dwds.de/ is also an excellent monolingual dictionary. This dictionary is intended for advanced learners of German. The main disadvantage of monolingual dictionaries, generally speaking, is the fact that beginners or pre-intermediate learners find very difficult to use them. Dictionary compiling is extremely difficult process which takes years and participation of variety of experts to finish. One word can have lots of meanings and it can be used in various contexts. In order to be considered competent for dictionary compiling, lexicographers should have extensive knowledge related to syntax, phonetics, phraseology etc. It is also desirable that lexicographers should be bilingual. Dictionaries are an important part of national heritage because they keep less frequent words from forgetting.

To summarize, our e-glossary is mainly based on words translation and does not include grammar characteristics and different contexts a word can be used in.

\section{ELECTRONIC GLOSSARY DEVELOPMENT}

This glossary has been fully developed by students of the Faculty of Informatics and Computing at Singidunum University. While writing down variety of new German words, students came to an idea of keeping all those words in an electronic form. E-glossary of this kind is a unique synthesis of philological and IT skills. E-glossary programming is impossible without not only JAVA knowledge but also the appropriate level of German language knowledge. By searching words in this glossary, students can learn a lot and by adding new words, they make their own contribution to its development. Since German has been studied at Singidunum University for two years and students have been learning language from the very beginning, the glossary consists of the vocabulary needed for A2 level 
of competence according to the European Framework of Reference for Languages. Vocabulary is in accordance with the book - Berliner Platz 1 NEU, Langenscheidt, by Christiane Lemcke, Lutz Rohrmann and Theo Scherling. The students of the Faculty of Informatics and Computing are not very keen on writing, so they prefer typing instead. Sometimes, they even type new words into their smart phones or ask for a permission to photograph the blackboard with words written on it. This method is also used by students of other study programmes, not only students of Informatics and Computing. This fact tells us that students nowadays learn languages in a different way. The e-glossary mentioned above is the most useful in tests preparation to the students who developed it. It does not include grammar. Also, it does not include plural form of nouns which is very important in German, because it is mainly learnt by heart. The issue which is raised here is whether students should learn difficult words before they learn simple ones; for example, should students learn animal or plant species before they learn the word animal or plant (das Tier, -e which means animal, die Pflanze, $-n$ which means plant). The same sentence can be finished in at least ten different ways, without major change in meaning. This is one example of it:

- Ich komme nicht, weil ich keine Lust habe.

- I will not come because I don't feel like coming.

- Ich komme nicht, weil ich schlecht gelaunt bin.

- I will not come because I am in a bad mood.

- Ich komme nicht, weil ich schlechte Laune habe.

- I will not come because I am in a bad mood.

- Ich komme nicht, weil ich gelangweilt bin.

- I will not come because I am bored.

- Ich komme nicht, weil ich nicht fit bin.

- I will not come because I am not fit.

The sentence can be changed grammatically and subordinate clause can be used instead of two simple ones.

- Ich komme nicht. Ich bin nicht im Stande.

- I am not capable of coming.

- Ich komme nicht. Ich fühle mich schlecht.

- I will not come. I do not feel very well.

Conjuction can also be changed.

- Ich habe keine Lust und deswegen komme ich nicht.

I don't feel like coming and that's why I won't come.

- Ich habe keine Lust und deshalb komme ich nicht.
I don't feel like coming and that's why I won't come. (The translation is the same but the conjuction is not.)

- Ich komme nicht, denn ich habe keine Lust.

I don't feel like coming and that's why I won't come. (The translation is the same but the conjuction is not.)

While learning a foreign language, students develop their own system of memorising new words and learning style as well. They have opportunity to role play, talk in front of the group, understand the importance of context, revise Serbian grammar, do pair work or group work (emphasis is on team work) and consequently, they are prepared for real life situations and their future careers. E-glossary is just one example of motivating the students to learn a foreign language. The advantages of e-glossary of this kind are: simple usage, maintainance and new words addition as well as search. It can be easily multiplied, moved, printed, depending on user's needs. There are various ways of keeping the data in electronic form. Some of them are conventional, widespread and usable on different platforms or operating systems. It can be simple textual, MS Excel or MS Word file. The development of this kind of e-glossary requires IT skills that an average computer user has. Also, the tools mentioned above, which are used for maintaining these kinds of files contain functionalities which can help while searching. Although we are more that aware of the fact that there are great number of various glossaries and dictionaries on the Internet, this e-glossary is likely to be the most useful to us, because it is unique in a way that it is compatible with curriculum and the vocabulary level taught at the faculty at the moment. The glossary consists of approximately 1000 words and phrases, but the new ones are being constantly added.

Writing on a piece of paper includes making inevitable mistakes. Sometimes, those mistakes can improve the process of learning itself. Mostly, if we write in a traditional way, on a piece of paper, mistakes corrections will remain as a reminder for us, in order not to repeat the same mistakes. That reminder is usually missing in electronic form.

If we use glossaries and dictionaries available on the Internet, we may search the same word or phrase more than once. There are some expressions we simply cannot memorise. If we keep our own records, when we repeat the action for the first time, we will immediately notice that we have already did the action and that certain word or phrase is difficult to remember. These were the initial reasons for creating our own glossary. The other reasons will be described later. 
As we have already said, two common electronic ways of keeping or searching words, files and the Internet dictionaries/glossaries are portable, that is to say, they can be used on almost all platforms. So, we also needed the programming language which can be used on most platforms for the purpose of creating this glossary. Java programming language has been a logical choice.

Java programming language is one of the most commonly used programming languages. One of the reasons is portability. Every programme has to be translated into machine language which is understood by computer processor. The job of translating is done by translators or interpreters, depending on the option language producers want. Translators translate complete programming code into machine code, whereas interpreters translate line by line. Consequently, special version of these programmes is needed for each processor. That fact inspired Java creators to develop combined solution. They introduced the layer which is located between the programme and processor. „Programmes written in Java are still being translated into machine language, but that machine language is not the real processor name but imaginatory computer called Java virtual machine (JVM). Java virtual machine language is called bite code“ (Živković, 2012:6). Java virtual machine interprets that code into appropriate processor machine language of our computer. In that way, Java bite code data file can be performed on any processor type, supported by Java virtual machine.

The important part of every application is the way we keep the data. There are two reasons for choosing text files. The first one is portability and the second one is the type itself-they can be read even without the application. As a structure used for data processing, the list is used. According to Živković, the list as an abstract data type has advantage in regard to data chain in practice where the related elements are being manipulated but the number of those elements is unknown (Živković, 2010:88). Considering the fact that we do not know how many words are going to be used, the list is more than suitable.

In users interface designing, we also go for Java programming language and Swing/AWT libraries. These libraries graphic components communicate with the operating system and take systematic appearance for windows, events management etc. „Actually, complete graphic programming in Java is based on JFC library
(Java Foundation Classes), which consists of Swing/ AWT and much more than that" (Živković, 2011:165).

\section{HOW TO USE}

Data entry file creation: By clicking on the button "add new source" the window is being opened and folder with the application in it should be found. New file name should be typed then.

Similarly, an existing one can be added, if chosen in the dialogue offered (picture I and II).

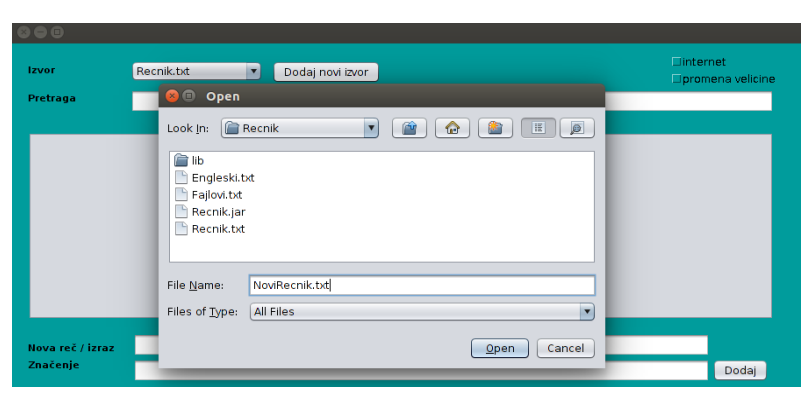

Picture 1.

Now we can access two options „New word/ Phrase“ and „Meaning“ and then click on „Add“ button (picture III).

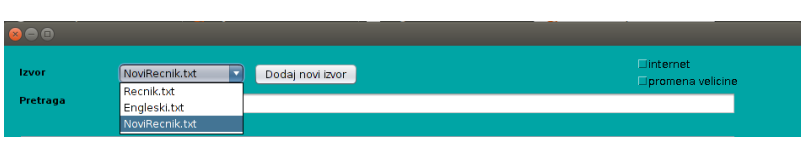

Picture 2.

In case we do not know the meaning of a word, by typing that word and searching it in the "Internet" option, web page with the word typed will be opened on Google Translate service from where we can take the meaning. The size change will reduce the window height so that the suggestions offered by Google can be seen (picture IV). Glossary can function without the Internet. The option of finding the word needed on the Internet can be also used.

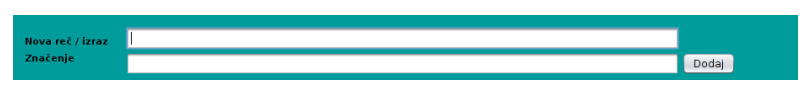

Picture 3. 


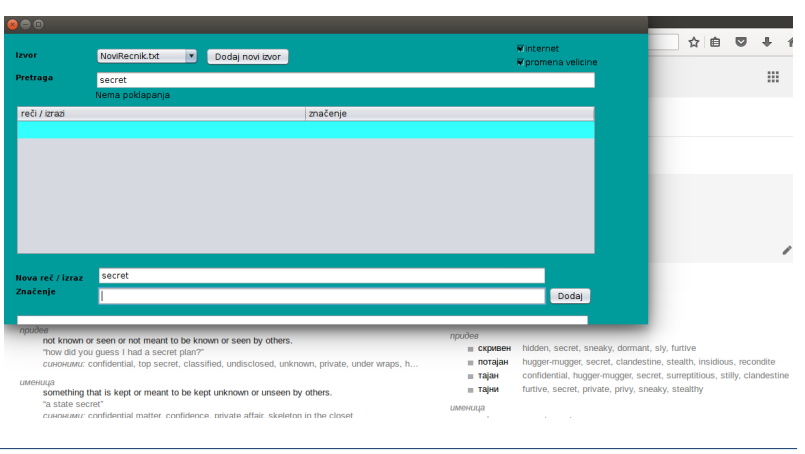

Picture 4.

The search of existing phrases is quite simple. Any character chain is searched in both columns-phrase and meaning (picture V).

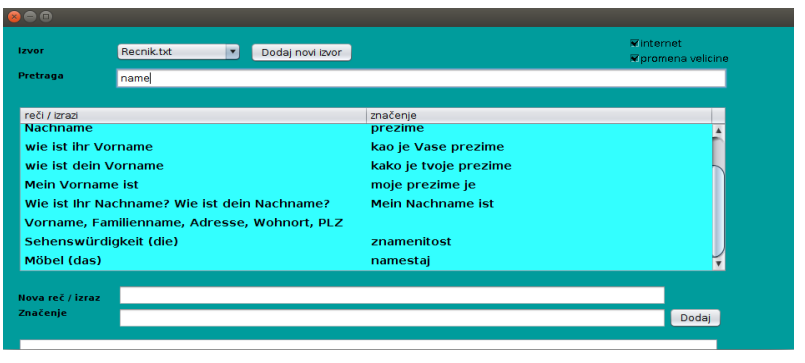

Picture 5.

Editor, located below the search option, include feature which can be activated by shortcut CTRL+SPACE. As picture VI shows, the list with the same result as in the search option, is activated. In that way, the user can choose the term he/she wants which will then be entered by using word search option, so „Ich misl“ will become "Ich denken" which can be furher improved in order to get the correct grammatical form. If we enter all the persons forms, singular and plural form, of a verb, there will be no need for corrections. The shortcut mentioned above activates the feature in the mode so as to use the left term from the list while entering. If we activate the shortcut by using F1, the right term will be entered instead the left one.

kch nis $[$ denken ! mistrit

\section{CONCLUSION}

The goal of electronic glossary development is a synthesis of philological and IT skills, programming and spoken languages and students' own initiative support. On one hand, this glossary motivated students in an original way and on the other hand, it proved to be very useful to them. Our glossary is not perfect, but it's goal has been fulfilled. Young generations add new words to it and offer some new solutions. This glossary has been a pioneering work and we expect lots of similar projects in the future.

\section{REFERENCES}

[1] Ferčec, I. and Šoštarić, B. (2006). Internet i nastava engleskog jezika na Tehničkim fakultetima. Život $i$ škola 15-16 (1-2), p. 115-122. Retrieved January 23, 2016, from http://hrcak.srce.hr/index. php?show=clanak\&id_clanak_jezik=39467

[2] Gabrilo, G. and Rodek, J. (2009). Učenje putem interneta- mišljenja i stavovi studenata. Časopis za pedagogijsku teoriju i praksu 58 (3), p.281-299. Retrieved January 23, 2016, from http://hrcak.srce.hr/ index.php?show=clanak\&id_clanak_jezik=122846

[3] Jeremić, V. (2010). Tehnološka tranzicija i promena kulturne paradigme. In Knjiga i jezik u razvoju savremenog društva. (p. 67-80). Beograd: Filološki fakultet.

[4] Šimunović, A. (2013). Motivacija studenata za učenje stranih jezika. Učenje za poduzetništvo 3 (2), p. 216-227. Retrieved January 23, 2016, from http:// hrcak.srce.hr/index.php?show=clanak\&id_clanak_ jezik=192692

[7] Živković, D. (2011). Java Programiranje. Beograd: Univerzitet Singidunum

[8] Živković, D. (2012). Osnove Java Programiranja. Beograd: Univerzitet Singidunum

[9] Živković, D. (2010). Uvod u algoritme i strukture podataka. Beograd: Univerzitet Singidunum

Picture 6. 